Imagining Asia in the Americas 


\section{Asian American Studies Today}

This series publishes scholarship on cutting-edge themes and issues, including broadly based histories of both long-standing and more recent immigrant populations; focused investigations of ethnic enclaves and understudied subgroups; and examinations of relationships among various cultural, regional, and socioeconomic communities. Of particular interest are subject areas in need of further critical inquiry, including transnationalism, globalization, homeland polity, and other pertinent topics.

Series Editor: Huping Ling, Truman State University

Stephanie Hinnershitz, Race, Religion, and Civil Rights: Asian Students on the West Coast, 1900-1968

Jennifer Ann Ho, Racial Ambiguity in Asian American Culture

Haiming Liu, From Canton Restaurant to Panda Express: A History of Chinese Food in the United States

Jun Okada, Making Asian American Film and Video: History, Institutions, Movements Kim Park Nelson, Invisible Asians: Korean American Adoptees, Asian American Experiences, and Racial Exceptionalism

Zelideth María Rivas and Debbie Lee-DiStefano, eds., Imagining Asia in the Americas

David S. Roh, Betsy Huang, and Greta A. Niu, eds., Techno-Orientalism: Imagining Asia in Speculative Fiction, History, and Media 


\title{
Imagining Asia in the Americas
}

\author{
EDITED BY \\ ZELIDETH MARÍA RIVAS \\ AND DEBBIE LEE-DISTEFANO
}

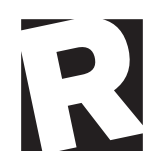

RUTGERS UNIVERSITY PRESS

NEW BRUNSWICK, NEW JERSEY, AND LONDON 
Library of Congress Cataloging-in-Publication Data Names: Rivas, Zelideth María, 1979- | Lee-DiStefano, Debbie.

Title: Imagining Asia in the Americas /

edited by Zelideth María Rivas and Debbie Lee-DiStefano.

Description: New Brunswick, New Jersey : Rutgers University Press, 2016. | Series: Asian American studies today | Includes bibliographical references and index. Identifiers: LCCN 2015047307| ISBN 9780813585215 (hardcover : alkaline paper) | ISBN 9780813585208 (paperback : alkaline paper) | ISBN 9780813585222 (ePub) | ISBN 9780813585239 (Web PDF)

Subjects: LCSH: Asia-Relations-America. | America-Relations-Asia. | AsiaForeign public opinion, American. | Asia-Foreign public opinion, Caribbean. | Asia-Foreign public opinion, Latin American. | Public opinion-America. | Asians-America-Social conditions. | Immigrants-America-Social conditions. |

Transnationalism-Social aspects-America. | Community life-America.

Classification: LCC DS33.4.A45 I47 2016 | DDC 303.48/25097-dc23

LC record available at http://lccn.loc.gov/2015047307

A British Cataloging-in-Publication record for this book is available from the British Library.

This collection copyright ( 2016 by Rutgers, The State University Individual chapters copyright ( 2016 in the names of their authors

All rights reserved

No part of this book may be reproduced or utilized in any form or by any means, electronic or mechanical, or by any information storage and retrieval system, without written permission from the publisher. Please contact Rutgers University Press, 106 Somerset Street, New Brunswick, NJ 08901. The only exception to this prohibition is "fair use" as defined by U.S. copyright law.

Visit our website: http://rutgerspress.rutgers.edu Manufactured in the United States of America 